\section{Further Reading}

Baker, Michael N. (ed.) International Criminal Court: Developments and U.S. Policy. 2012

Macedo, Stephen, (ed.) Universal Jurisdiction: National Courts and the Prosecution of Serious Crimes Under International Law. 2003

Mendes, Errol, Peace and Justice at the International Criminal Court: A Court of Last Resort. 2010

Reydams, Luc, Universal Jurisdiction: International and Municipal Perspectives. 2003

Schabas, William A., An Introduction to the International Criminal Court. 4th ed. 2011

Struett, Michael J., The Politics of Constructing the International Criminal Court: NGOs, Discourse, and Agency. 2008

\section{International Institute for Democracy and Electoral Assistance (IDEA)}

Created in 1995, International IDEA is an intergovernmental organization that supports sustainable democratic change through providing comparative knowledge, assisting in democratic reform, and influencing policies and politics. International IDEA focuses on the ability of democratic institutions to deliver a political system marked by public participation and inclusion, representative and accountable government, responsiveness to citizens' needs and aspirations, and the rule of law and equal rights for all citizens.

Aims and Activities. International IDEA undertakes work through three activity areas: providing comparative knowledge derived from practical experience on democracy-building processeselections and referendums, constitutions, political parties, women's political empowerment and democracy self-assessments-from diverse contexts around the world; assisting political actors in reforming democratic institutions and processes, and engaging in political processes when invited to do so; influencing democracybuilding policies and assistance to political actors.

Membership. International IDEA had 28 full member states and one observer state in Feb. 2016.

Organization. International IDEA has regional operations in Latin America, Africa, the Middle East, Asia and the Pacific, and has a staff of over 70 worldwide.

Headquarters: Strömsborg, 10334 Stockholm, Sweden.

Website: http://www.idea.int

Secretary-General: Yves Leterme (Belgium).

\section{International Mobile Satellite Organization (IMSO)}

Founded in 1979 as the International Maritime Satellite Organization (Inmarsat) to establish a satellite system to improve maritime communications for distress and safety and commercial applications. Its competence was subsequently expanded to include aeronautical and land mobile communications. Privatization, which was completed in April 1999, transferred the business to a newly created company and the Organization remains as a regulator to ensure that the company fulfils its public services obligations. The company has taken the Inmarsat name and the Organization uses the acronym IMSO. In Feb. 2016 the Organization had 101 member parties.
Organization. The Assembly of all Parties to the Convention meets every two years.

Headquarters: 99 City Road, London EC1Y 1AX, UK.

IMSO Website: http://www.imso.org

Email:info@imso.org

Inmarsat Website: http://www.inmarsat.com

Director General, IMSO: Capt. Moin Ahmed (Bangladesh).

Chief Executive, Inmarsat Ltd: Rupert Pearce

(United Kingdom).

\section{International Olympic Committee (IOC)}

Founded in 1894 by French educator Baron Pierre de Coubertin, the International Olympic Committee is an international nongovernmental, non-profit organization whose members act as the IOC's representatives in their respective countries, not as delegates of their countries within the IOC. The Committee's main responsibility is to supervise the organization of the summer and winter Olympic Games. It owns all rights to the Olympic symbols, flag, motto, anthem and Olympic Games.

Aims. 'To contribute to building a peaceful and better world by educating youth through sport, practised without discrimination of any kind and in the Olympic Spirit, which requires mutual understanding with a spirit of friendship, solidarity and fair play.'

Finances. The IOC receives no public funding. Its only source of funding is from private sectors, with the substantial part of these revenues coming from television broadcasters and sponsors.

Address: Château de Vidy, Case Postale 356,

CH-1007 Lausanne, Switzerland.

Website: http://www.olympic.org

President: Thomas Bach (Germany).

\section{International Organisation of La Francophonie}

The International Organisation of La Francophonie represents 80 countries and provinces/regions (including 23 with observer status) using French as an official language. It estimates that there are $220 \mathrm{~m}$. French speakers worldwide. Objectives include the promotion of peace, democracy, and economic and social development, through political and technical co-operation. The Secretary-General is based in Paris.

Members. Albania, Andorra, Armenia, Belgium, Benin, Bulgaria, Burkina Faso, Burundi, Cabo Verde, Cambodia, Cameroon, Canada, Canada-New Brunswick, Canada-Quebec, Central African Republic, Chad, Comoros, Democratic Republic of the Congo, Republic of the Congo, Côte d'Ivoire, Djibouti, Dominica, Egypt, Equatorial Guinea, France, French Community of Belgium, Gabon, Greece, Guinea, Guinea-Bissau, Haiti, Laos, Lebanon, Luxembourg, Macedonia, Madagascar, Mali, Mauritania, Mauritius, Moldova, Monaco, Morocco, Niger, Romania, Rwanda, St Lucia, São Tomé e Príncipe, Senegal, Seychelles, Switzerland, Togo, Tunisia, Vanuatu, Vietnam. Associate Members. Cyprus, Ghana, Qatar. Observers. Austria, Bosnia and Herzegovina, Costa Rica, Croatia, Czech Republic, Dominican Republic, Estonia, Georgia, Hungary, Kosovo, Latvia, Lithuania, Mexico, 